\title{
A RELIABILITY ANALYSIS METHOD OF CLOUD THEORY - MONTE CARLO BASED ON PERFORMANCE DEGRADATION DATA
}

\author{
OPARTA NA TEORII CHMURY I MODELU MONTE CARLO METODA \\ ANALIZY NIEZAWODNOŚCIOWEJ DANYCH O OBNIŻENIU CHARAKTERYSTYK
}

\begin{abstract}
Owing to inadequate degradation data, the randomness and the fuzziness of degradation processes, it is difficult to calculate the reliability of product. By investigating performance reliability using degradation data of performance, the authors proposed a method of analyzing reliability of performance degradation data using Monte Carlo principle and cloud theory. First of all, the performance degradation cloud with the degradation amount and the entropy which denotes the possible discrete degree of the degradation data, is generated by using performance degradation data and a cloud theory forward cloud generator. Then, the minimum membership threshold of cloud droplets and the threshold of product failure were set. Meanwhile, the number of cloud droplets that comply with the minimum membership degree and the failure threshold were counted. Finally, the reliability method of performance degradation data was proposed by using the principle of Monte Carlo and the cloud theory. In this work, the cloud theory was introduced to verify the reliability of the performance degradation of the product. The randomness and the fuzziness in the degradation tests are resolved. In addition, due to the limits of degradation test data, the difficulties in calculation of the reliability is resolved using the principle of Monte Carlo, the minimum membership of cloud droplets and its minimum degree are therefore guaranteed. This work provides a new method of simulating the reliability of degradation. The feasibility of the method was validated by an example ensuring a high durability of conveyor belt joints is tantamount to guaranteeing their reliable operation and that the results of research conducted so far fail to provide unambiguous solutions to a number of problems that emerge in this case, it is advisable that advanced studies using computer techniques should be conducted within this area.
\end{abstract}

Keywords: performance degradation; Cloud theory; Monte Carlo Method; Randomness; Fuzziness.

\begin{abstract}
Ze względu na niewystarczajace dane o degradacji oraz losowość i rozmycie procesów degradacji, obliczanie niezawodności produktu jest zadaniem trudnym. Chcac badać niezawodność przy użyciu danych dotyczacych obniżenia charakterystyk, autorzy zaproponowali metodę analizy danych o obniżeniu charakterystyk wykorzystujaca zasady metody Monte Carlo oraz teorii chmury. Po pierwsze, wykorzystując dane o obnizeniu charakterystyk oraz progresywny generator chmur, wygenerowano chmure obniżenia charakterystyk zawierająca dane na temat stopnia degradacji oraz stopnia entropii, która określa możliwy dyskretny stopień degradacji danych. Następnie, ustalono minimalny próg przynależności punktów chmury oraz próg uszkodzenia produktu. Policzono liczbę punktów chmury które spetniały warunek minimalnego stopnia przynależności oraz progu uszkodzenia. Wreszcie, zaproponowano metodę analizy niezawodnościowej danych o obniżeniu charakterystyk wykorzystująca zasady modelu Monte Carlo oraz teorii chmury. W pracy przedstawiono teorię chmury, która pozwala na weryfikację niezawodności danych of obniżeniu charakterystyk produktu. Rozwiązano w ten sposób problem losowości i rozmycia wystęujące w badaniach degradacji. Ponadto, przy użyciu metody Monte Carlo, rozwiazano trudności w obliczaniu niezawodności związane z ograniczeniami danych z badań degradacji, co zagwarantowało minimalna przynależność punktów chmury oraz minimalny stopień uszkodzenia. $W$ prezentowanej pracy przedstawiono nowa metodę symulacji niezawodności danych o degradacji. Poprawność przedstawionej metody zweryfikowano na podstawie przykładu. Zapewnienie wysokiej trwałości złączy taśmy przenośnikowej jest równoznaczne z zapewnieniem ich niezawodnej pracy, a ponieważ wyniki prowadzonych dotąd badań nie dostarczaja jednoznacznych rozwiazań wielu wyłaniajacych się w tym przypadku problemów, wskazane jest prowadzenie w tym zakresie zaawansowanych badań z użyciem technik komputerowych.
\end{abstract}

Stowa kluczowe: obniżenie charakterystyk, teoria chmury, metoda Monte Carlo, losowość, rozmycie.

\section{Introduction}

The failure of products mainly results from the combined action of its own factors and external conditions [3]. The failure forms can be divided into two types: the basic properties of the product before failure is intact, as in a moment, suddenly all functions are lost; this kind of failure is called sudden failure [36]. For example, when using mechanical products, failure occurs due to the load which is greater than allowable value applied; In contrast with the sudden failure, the other kind is degradation failure whose main performance becomes slowly worse with the increase of time and frequency. When the performance is lower than the lowest limit [37], the product loses its function. Before the products' failure, the degradation failure type undergoes a process changing quantitatively and then qualitatively, it is the main failure form of most of products in the process of normal use and is also the main reason for the shortening of service life. There are many reasons for the performance degradation of the products, and different products have different mechanisms of the degradation. For example, Wang XD, Yi Z and Shen ZC carried out radiation experiments for white paint (S781) in a simulated space environment, to test the spec- 
tral reflectance and the rule of the solar absorptance degradation, and found that Zinc vacancy is the main reason of the optical degradation of S781 white paint [24]. The failure of steel tube is caused by too deep or too many pits on the surface. To study the failure mechanism of the depth and density growth of steel tube surface pit with time and pressure, a new model of steel tube was put forward by M. Nuhi under different temperature and different environment pressure aiming [11]. The research on the mechanism of degradation products is to study the concern question using the degradation law. Among which, degradation rule of the products was widely used to study the reliability of the products. For example, in view of two parameters related situation for the product in the degradation process and based on gamma process product in literature [15], a variety of performance characteristics of the degraded reliability model was proposed using binary Birnbaum-Saunders and its edge distribution. In literature [21], the degradation process for gamma random process and the strong laser device reliability were analyzed by using the method of simulation. Based on single chip ceramic dental implants in autoclave with radiation environment and the steam fatigue aging environment test in literature [1], ceramic surface of porous implants rule and its reliability of the mechanical performance degradation were studied. A more comprehensive reliability model for correlation failure in failure mode of long life product under real-time copulas was established using the degradation data of products in literature [22]. In order to more effectively diagnose the malfunction position of rolling bearing, the different performances of degradation degree of bearing, and the method of finding the position of the bearing fault and the intelligent classification of fault type features, the EMD bearing fault diagnosis methods were put forward based on collection optimization in literature [25]. The residual life prediction method for thermal aging of the reliability of casting austenitic stainless steel pipe used in light water reactor was studied in literature [19] under high temperature working conditions.

However, for some high value and long life products, small sample is the main obstacle for researching the reliability of the products concerning degradation method and reliability using the degradation data [20]. Aiming at this problem, domestic and foreign scholars have done a lot of works. A degradation test was performed for six main parameters of pricing function module of the smart meter using the method of accelerated degradation in the literature [33]. The degradation path of billing module of smart meters and the failure probability were measured by fitting the degradation data and using the extrapolation degradation path under different times. The metal covering current leakage and hydrophobic on the surface of lightning rod was measured with the increase of time by soaking the lightning rod in salt water at $90^{\circ} \mathrm{C}$ and performance degradation and time relations as well as the reliability of the over time was obtained in the literature [2]. As accelerated degradation tests carried out for products in the lab fail to achieve the use of real environment, the integrated field-use and laboratory accelerated degradation test information was put forward in the literature [26] for Bayesian method of reliability assessment and markov chain Monte Carlo method. Considering the difficult problems of data extraction by sequential degradation product in complex dynamic failure mode, the implementation of the product, and the reliability and prediction in the long-term level, the reliability of the product degradation and state level predicted by the complex neurons were proposed using feed forward neural network of multilayer in literature [13]. Accelerated degradation tests were conducted in literatures [35] and [38] to study the reliability evaluation for the performance degradation of metallized film capacitor and the problems of metallized film pulse capacitor. Owing to various reasons, such as human and environmental, degradation process is associated with uncertain information. It was assumed in literature [9] that the randomness of performance degradation path and the performance reliability of the cumulative distribution function curve of plunger pump were obtained by using an efficient Monte Carlo simulation method. As ambiguity exists in the process of degradation problems, the reliability methods for assessing the performance degradation were proposed based on fuzzy $\mathrm{C}$ - average clustering, and the degradation of fatigue life of 6307 rolling bearing was evaluated in literature [14]. Product reliability was calculated by the degradation process of products and the threshold was considered with blind number type in literature [28] respectively. The reliability of the degradation data of products was discussed in literature [29] under the condition of degradation threshold for fuzzy numbers.

Most of the above mentioned literatures assume that the degradation obeys a certain distribution; then the distribution evaluate, calculate and predict the reliability of the product or life by fitting the degradation curve. This approach can be implemented by a small number of data reliability for the whole life prediction of the products. But in actual application, for some products, we merely need to pay attention to the reliability of some key degradation time points. The key degradation time points need to be set in advance, otherwise it is difficult to observe the degradation value accurately [10]. While little care is needed for the rest of the points, even some long life products, which can get products by carrying out accelerated degradation tests for the whole life of the data in reliability assessment for the life of the products. For example, some of the key time points just need to be known before the product reaches the period of validity or effective and to verify whether the product's reliability conforms to the requirements. If not, the reliability of the product has to be improved. In the reliability test for degradation of some high value products, due to the limitation of experimental factors such as cost, little degradation experiment data were obtained only for small batch. Therefore, apart from the specimen quality was contained in the degradation of the test data and test conditions are caused by randomness, the ambiguity is caused by factors such as test operator as well. For these problems, scholars at home and abroad studied the randomness and fuzziness problems in the process of performance degradation using Poisson process - Normal [16], Monte Carlo simulation [9], neural network [4], fuzzy C - average [14], logistic regression [34], hidden Markov model [12] methods, respectively. However, in general, all the existing methods in the process of the degradation are still in exploration. In the paper, cloud theory is introduced in the degradation process of products in a certain amount of degradation time, by using numbers of cloud droplets in cloud theory generated and screening to meet the requirements of minimum membership of cloud droplets. It ensures that cloud droplets participate in the operation relating the degradation of membership degree, by using the Monte Carlo reliability principle to finally focus on the reliability of moment.

\section{Cloud Theory}

Cloud theory was put forward by Chinese scholar Li DY. The core of Cloud theory is cloud droplets, which not only show the characteristics of probability distribution of random theory, but also have the concept of membership degree in fuzzy comprehensive. The theory realizes the common description of two kinds of uncertainty problems. Since been proposed, cloud theory has already been widely used in computer simulation, reliability evaluation, etc. For example, because it is difficult to quantitatively evaluate the reliability of combat aircrafts, the theory of cloud implements the quantitative reliability evaluation of battle classification by translating the qualitative data into quantitative data [27]. Based on cloud theory, the cloud droplets containing the distribution function of the random process are the membership function of fuzzy theory, which was be studied in the literature [17] as well. For complex system in the assessment, there are abundant uncertainty information and requirements for multiple hierarchy comprehensive evaluation, combining with the cloud theory and the theory of information fusion system performance evaluation 
methods which were proposed in literature [18]. With comprehension of the integrated reliability of road network combining cloud theory, radar map and road network, an integrated reliability evaluation was proposed in literature [7] based on cloud theory and radar map. For cloud computing problem of information security and reliability, a new reverse algorithm for cloud depth was proposed, and the algorithm has been applied to the trust of online trading decisions in literature [8]. Aimed at the uncertainty in the spatial load forecasting model of distribution network, knowledge based on cloud model was put forward according to a new spatial load forecasting model of distribution network. Meanwhile, this model implements quantitative and qualitative mappings to each other in literature [32].

\subsection{Definition of Cloud}

$U$ is a precise value of domain in quantitative theory. $C$ is the qualitative concept on the $U$. If quantitative values $x \in U$ and $U$ are a random qualitative concept of $C$ implementation about $x$, uncertainty $u(x)$ of $C, x \in[0,1]$ is a steady tendency of random numbers. That is:

$$
u: U \rightarrow[0,1], \forall x \in U \quad x \rightarrow u(x)
$$

$u: U \rightarrow[0,1], x$ in the theory of domain $U$ called cloud, the distribution of each $x$ is a cloud droplets.

\subsection{Characteristics of Cloud [6]}

(1) The domain $U$ of cloud theory can be one-dimensional and multi-dimensional as well.

(2) The random implementation and membership degree of randomness and fuzziness of relevance are related to the distribution of probability theory and fuzzy setting membership function.

(3) Any map of $x$ to the interval $[0,1]$ is a one-to-many transformation; the uncertainty of $x$ in $C$ is a probability distribution, instead of a fixed value.

(4) Cloud is composed of cloud droplets. There is no order among cloud droplets. A cloud droplet is an implementation of qualitative concept in quantity. The more cloud droplets, the more the overall characteristics of the qualitative concept can reflect.

(5) Both the appearing probability and the uncertainty of cloud droplets are large, so the cloud droplets contribute more to the concept.

\subsection{Positive Generator and the Process of Cloud}

There are three kinds of cloud generators, including Positive generator, adverse generator and conditions generator [23]. Positive generator generates random point and its corresponding membership degree using the data of the expectation, variance and dispersion degree of data as the basic input parameters. It is the commonly used method for generating random points, as shown in Fig. 1.

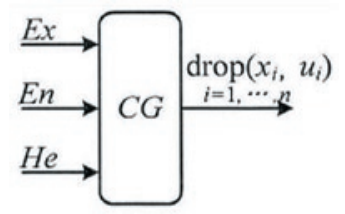

Fig. 1. Positive Cloud generator

\subsection{The formation of performance degradation of cloud droplets}

Assuming that a certain degradation test that has $m$ test samples with rule-type performance degradation test, at given time points in the number of $\mathrm{n}\left(t_{1}<t_{2}<\cdots t_{n}\right)$, respectively. The same method is used to measure the degradation of data samples, the measured Degradation data as follows:

$$
\begin{aligned}
& x_{11}, x_{12}, \cdots x_{1 n} \\
& x_{21}, x_{22}, \cdots x_{2 n} \\
& \ldots \\
& x_{m 1}, x_{m 2}, \cdots x_{m n}
\end{aligned}
$$

For the $i$-th amount of degradation products $x_{i t_{j}}$ at the time for $t_{j}$ point, by using the cloud droplets as the generator, the $i$-th product in the $t_{j}$ moment is generated based on the amount of cloud droplets of degradation $x_{i t_{j}}$. Steps are as follows:

(1) With the $\mathrm{i}$ th product at $t_{j}$ moment in degradation $x_{i t_{j}}$ as the expectation $E x_{i t_{j}}$ of the occurrence of cloud droplets, all of the degradation values of the specimens at $t_{j}$ moment determine the discrete degree amount of degradation products in ${ }^{t_{j}}$ time and the entropy $E n_{i t_{j}}$ of $i$ th product in $t_{j}$ moment of cloud droplets generator. At the same time, at the degree of quantitatively estimated discrete, the hyper entropy of cloud droplets generator is determined.

(2) Expectations for $E n_{i t_{j}}, H e_{i t_{j}}^{2}$ for the variance of a normal random number $E n_{k i t_{j}}^{\prime}$ are produced [23].

(3) Expectations for $E x_{i t_{j}}, E n_{k i t_{j}}^{2}$ for the variance of a normal random number $x_{k i t_{j}}$ are produced. Random number $x_{k i t_{j}}$ corresponding to the membership degree was calculated as follows:

$$
u_{k i t_{j}}=e^{-\frac{\left(x_{k i t_{j}}-E x_{i t_{j}}\right)^{2}}{2 E n_{k i t_{j}}^{2}}}
$$

(4) With membership degree $u_{k i t_{j}}$ and normal random number $x_{k i t_{j}}$, a cloud droplet was formed as drop $\left(x_{k i t_{j}}, u_{k i t_{j}}\right)$;

(5) According to the preset number, step (2) to step (4) were repeated to meet the required number of cloud droplets, as shown in Fig. 2.

As the normal random number was generated in normal distribution in step (2) and (3), literature [5] showed that the normal distribution was effective and correct.

According to the method, the specimen degradation experiment was carried out using the key time point cloud amount of degradation, as shown in Fig. 3. 


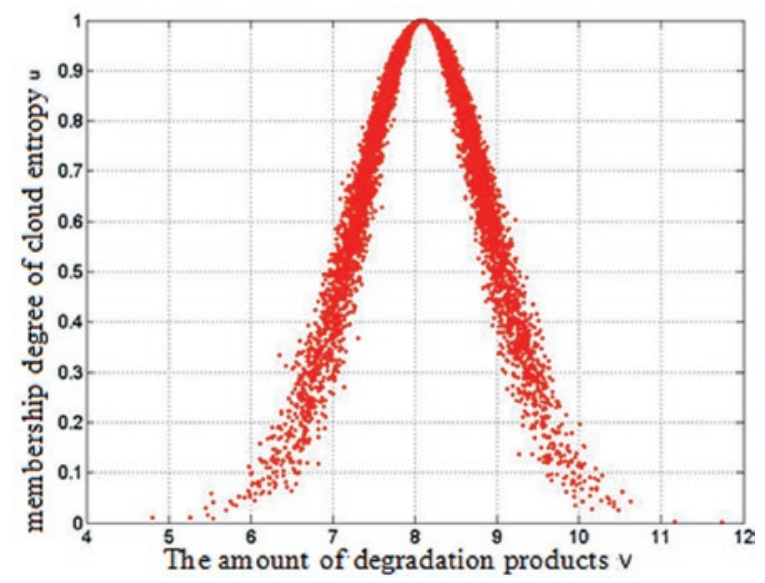

Fig. 2. Degradation cloud generated by one degradation point

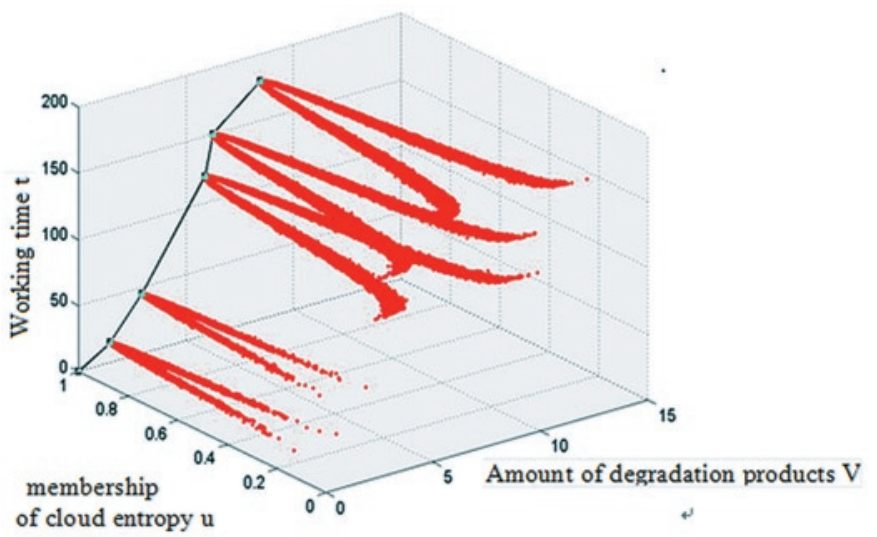

Fig. 3. Degradation Cloud generated by the amount of degeneration of a degraded sample at five key time points

\section{Monte Carlo method based degraded reliability of cloud}

\subsection{Monte Carlo Method}

Monte Carlo method, as a probability simulation method, is also known as random sampling techniques or test method. At the same level, it is a stochastic simulation method. It is a random sampling method based on the theory of probability, stochastic process and mathematical statistics. It is in accordance with the rules of sampling, which generates a large number of random Numbers. The generated random Numbers and part of the test data were used for studying quantities, and the distribution of data is therefore obtained. The limited experiment data in scientific research commonly lead to a low reliability. The random Numbers produced by Monte Carlo method provide supplementary for the test data, and expand the samples analysis. The small sample is solved by the numerical calculation of the randomness of problem. The results of credibility research increase. Practice shows that by using Monte Carlo method, the required accuracy can be satisfied in the generation of a sufficient number of random Numbers.

In reliability, because the probability of the appearance of an event can be solved using Monte Carlo method, this kind of event probability is obtained by using the method of sampling. The small sample data reliability is one of the main problems, so Monte Carlo method has been widely used in the reliability problems, which is agreed by scholars. The basic idea of Monte Carlo method for solving product reliability is to set a large number of random Numbers of events and boundaries, and the number of random number more than threshold value and the total number of random Numbers using Monte Carlo method in accordance with the rules produced. Then, the probability of events, which is the ratio of the number of random number more than threshold value to the total number of random Numbers, can be obtained [31].

\subsection{Cloud - Reliability Calculation Method of Monte Carlo Method Based on the Theory of Performance Degrada- tion Data}

In the process of degradation test, especially in the less degradation experiments, due to various causes of the uncertainty of degradation test data, reliability calculation shows big error by calculating the degradation data of the products under the condition of limited data collection and performance degradation. Monte Carlo method solves the randomness problem of the products in the process of the performance degradation caused by the limited data. But in the actual degradation test, especially in condition with limited degradation test data, because of factors such as the understanding of the limitations, the degradation data owned by the division has the characteristics of ambiguity, which is based on the research on the reliability and the randomness of the product performance degradation. The randomness and fuzziness is more serious. In order to solve the coexistence of randomness and fuzziness in the process of data degradation, the cloud droplets, which present the characteristics of randomness and fuzziness, in the theory of cloud is adopted based on Monte Carlo method. With the expected degradation $x_{i t_{j}}$ in $t_{j}$ time quantity for $i$-th product, performance degradation of cloud model is generated in $t_{j}$ moment, and the minimum membership threshold of the cloud droplets of products is set, as shown in Fig. 4. Meanwhile, the product failure threshold is set, as displayed in Fig. 5. The number of the $i$-th product cloud droplets which satisfy the requirement of minimum membership at time $t_{j}$ are counted, then The number of The $i$-th product cloud droplets which satisfy the requirement of minimum membership and exceed the degradation threshold at time $t_{j}$ are counted. Eq. (2) shows the calculation of reliability of products meeting certain membership requirements of performance degradation with $i$ in $t_{j}$ time.

$$
R_{i}\left(t_{j}\right)=1-\frac{\sum_{k=1}^{M} C_{t_{j}}\left(\operatorname{drop}_{i}\left(\left(x_{k i t_{j}}, \mu_{k i t_{j}}\right)\left(\left(\mu_{k i t_{j}}>\mu_{g}, x_{k i t_{j}}>T H\right)\right)\right)\right.}{\left.\sum_{k=1}^{M} C_{t_{j}}\left(\operatorname{drop}_{i}\left(\left(x_{k i t_{j}}, x_{k i t_{j}}\right)\right)\left(x_{k i t_{j}}>\mu_{g}\right)\right)\right)}
$$

where:

$x_{k i t_{j}}$ is the $k$-th random number caused by the amount of degradation in the first degradation test at time $t_{j}$.

$\mu_{k} \quad$ is the membership of the $k$-th random number $x_{k i t_{j}}$ caused by the amount of degradation in the first degradation test at time $t_{j}$.

$\mu_{g} \quad$ is the minimum membership of the random number

TH is the failure threshold of product performance degradation

$\operatorname{drop}_{i}\left(\left(x_{k i t_{j}}, \mu_{k i t_{j}}\right)\left(\mu_{k i t_{j}}>\mu_{g}, x_{k i t_{j}}>T H\right)\right)$ is the cloud droplets meeting the membership degree, which is greater than the minimum membership degree. It is larger than the failure threshold of performance degradation of random number;

$M \quad$ is the total number of random number: 


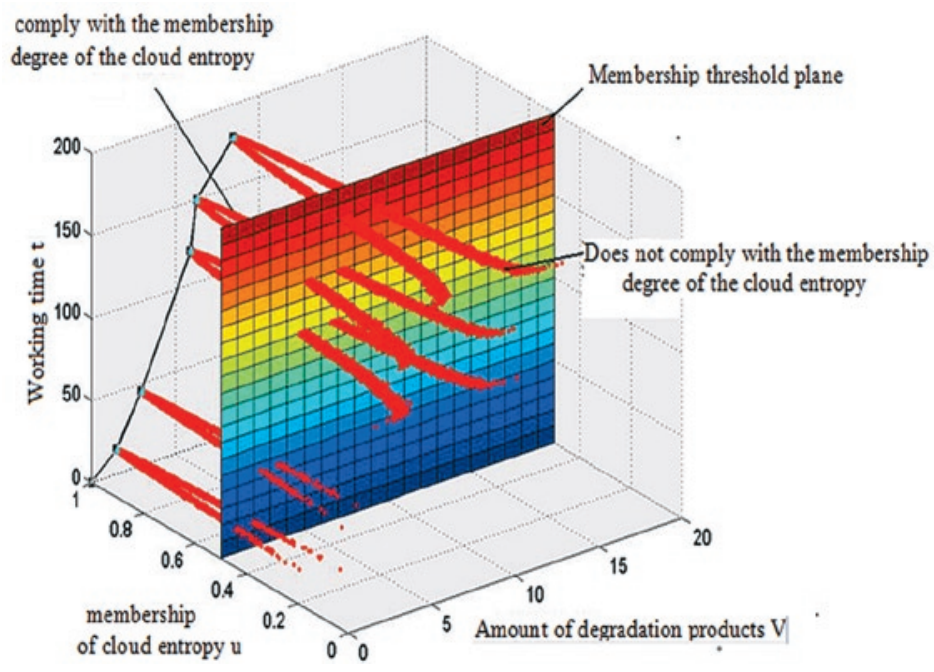

Fig. 4. Sketch map of setting the minimum threshold of degradation cloud

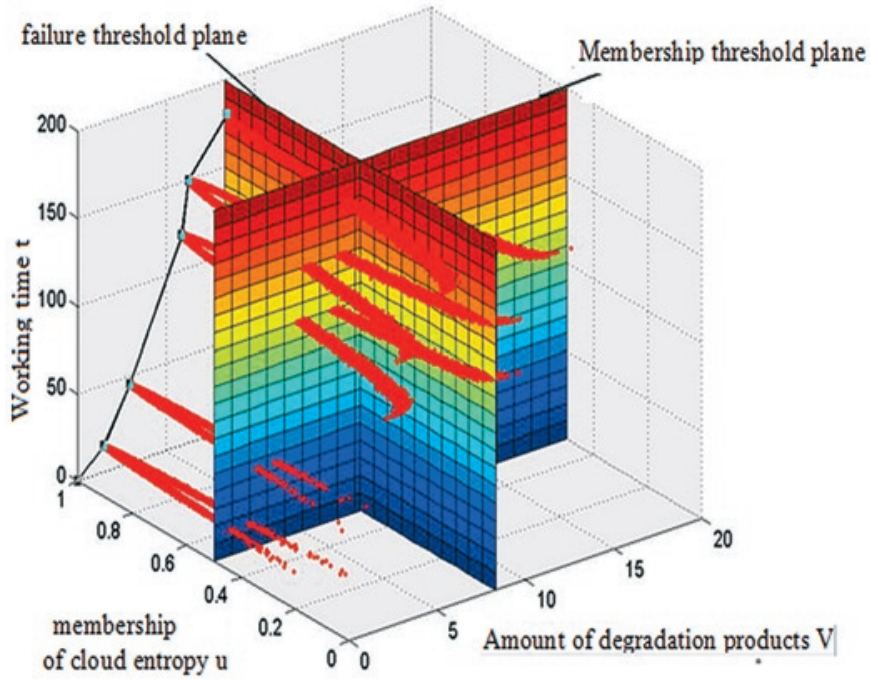

Fig. 5. Sketch map of setting the minimum threshold and membership threshold of degradation cloud

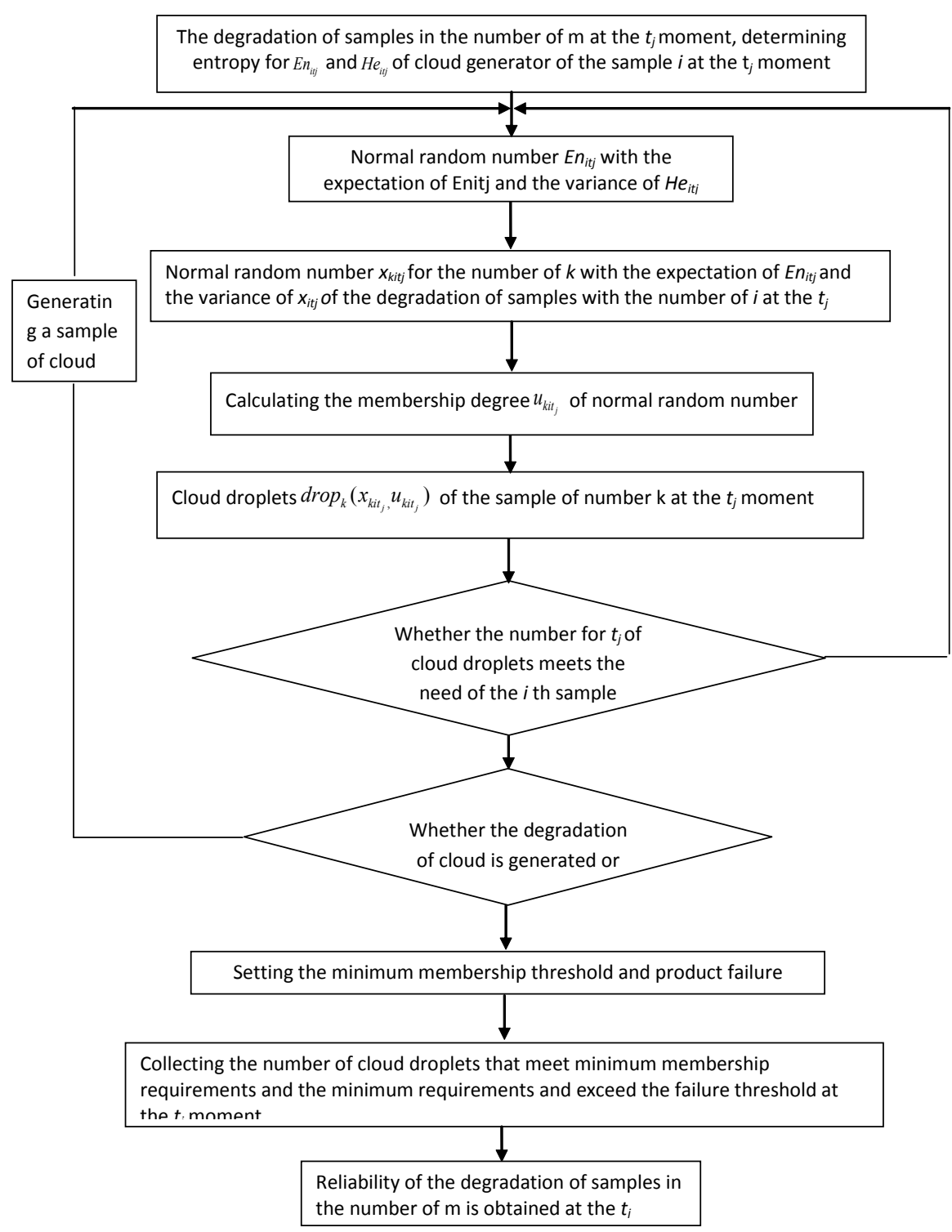

Fig. 6. Reliability calculation flowchart of degradation simples in the number of $m$ at
$\sum C_{t_{j}}(\bullet)$
is the number of cloud

droplets which meet the requirements.

The above method for calculating the credible degree at a crucial moment by using Monte Carlo method and the cloud theory sets a degradation process of the degradation sample as an example. The method for calculating the reliability of the degradation test samples in the number of $\mathrm{m}$ is similar to the above one, as illustrated in the Fig. 6.

\section{Example}

The reliability of the degradation of the example was analyzed in literature [33] and by Yang and Xue in literature [30] based on stochastic process method. This paper also used the data in literature [30] as an example, which demonstrates the process of the calculation method.

The data for product degradation test are shown in Table 1 . The quantity degradation with time is illustrated in Fig.7. The sample quantity in the tests is 7 , the measuring frequency is 5 , and each point is measured for $15 \mathrm{~h}, 45 \mathrm{~h}, 120 \mathrm{~h}$, $150 \mathrm{~h}$ and $180 \mathrm{~h}$.

Degradation cloud droplets were established using the performance degradation of each product during the expected observation time, as demonstrated in Fig. 8. Fig. 9 indicates that the minimum membership threshold of cloud droplets is 0.5 , and the product failure threshold is 8.5 .

Based on the degradation values generated by above seven samples of cloud droplets, the reliabilities of the products in the five key points of events are calculated according to the Eq. (2), and the results are demonstrated in Table 2.

\section{Conclusion}

As the reliability of the key point in time is calculated based on the product degradation data and the small amount of data in the process 
Table 1. Measured degradation data

\begin{tabular}{|c|c|c|c|c|c|c|c||}
\hline Time $t / \mathrm{h}$ & $V_{1}$ & $V_{2}$ & $V_{3}$ & $V_{4}$ & $V_{5}$ & $V_{6}$ & $V_{7}$ \\
\hline 0 & 0 & 0 & 0 & 0 & 0 & 0 & 0 \\
\hline 15 & 1.472 & 1.839 & 1.472 & 1.839 & 1.839 & 1.839 & 2.575 \\
\hline 45 & 2.943 & 4.047 & 3.311 & 2.943 & 3.311 & 2.943 & 3.679 \\
\hline 120 & 5.886 & 6.990 & 5.886 & 4.415 & 5.518 & 5.886 & 5.886 \\
\hline 150 & 6.254 & 8.093 & 6.622 & 5.150 & 6.254 & 6.990 & 7.726 \\
\hline 180 & 8.461 & 9.933 & 8.093 & 6.622 & 7.726 & 8.461 & 10.301 \\
\hline $\begin{array}{c}\text { Note: } V_{i}(i=1,2,3 \ldots, \\
\text { 7) is the } \text { ith sample. }\end{array}$ & & & & & & & \\
\hline \hline
\end{tabular}

of the degradation products and the degradation experiment shows randomness and fuzziness, the cloud theory was introduced into the calculation of the reliability of the performance degradation data. By using the theory of cloud, a large number of random and membership degree of cloud droplets were generated, cloud droplets meeting the requirements of minimum membership were selected and the failure threshold was set. The reliability of some time points was calculated using Monte Carlo method.

Based on the proposed method, the
Table 2. Reliabilities calculated at each key point

\begin{tabular}{|c|c|c|c|c|c||}
\hline time & 15 & 45 & 120 & 150 & 180 \\
\hline reliability & 1 & 1 & 1 & 0.9620 & 0.5175 \\
\hline
\end{tabular}

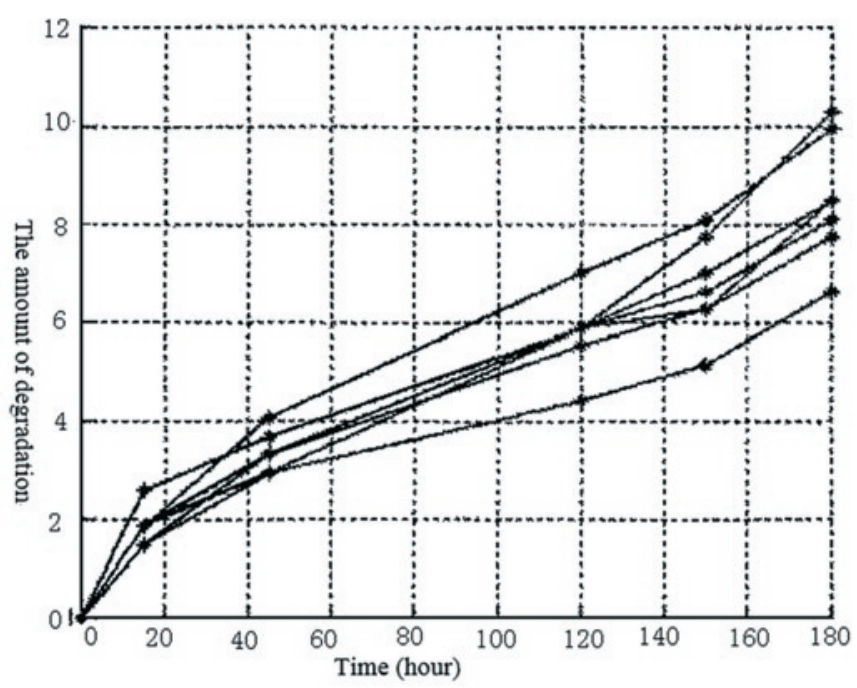

Fig. 7. the variation of the degradation of the seven samples with time

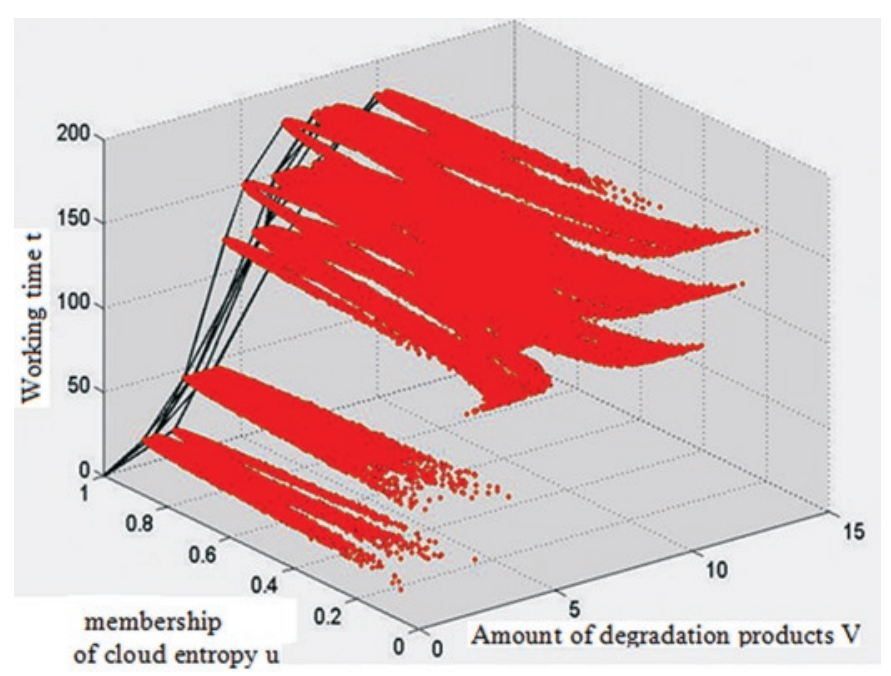

Fig. 8. Degradation cloud generated by the degradation amount of seven samples

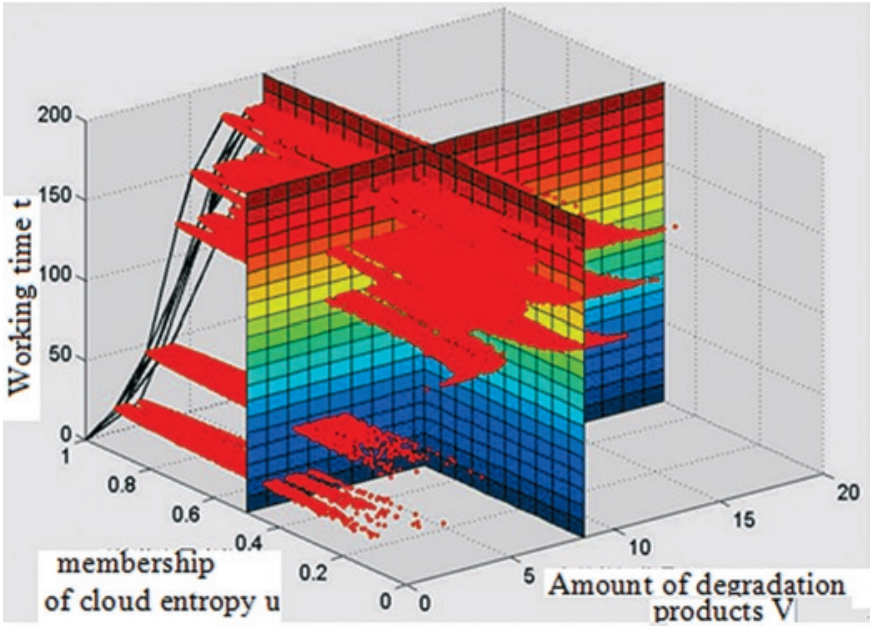

Fig. 9. Degradation cloud of setting minimum threshold and membership threshold

product reliability was 0.5175 at $180 \mathrm{~h}$. The reliability of 0.5489 was calculated merely considering the randomness in the process of degradation in literature [37]. By analyzing the data in Table 1, the average degradation data at $180 \mathrm{~h}$ reached 8.514, which was higher than that of the threshold (8.5). So, the method put forward in this paper is superior to that in literature [37].

\section{Acknowledgement}

This research was supported by the National Natural Science Foundation of China (Grant No.51275329) and the National "12th

Five-year" Science and Technology support plan (Grant No. 2011BAK06B05) and Natural Science Foundation of Shanxi province(Grant No.2015011059). 


\section{References}

1. Clarisse Sanon. Low temperature degradation and reliability of one-piece ceramic oral implants with a porous surface. Dental materials 2013; 29: 389-397, http://dx.doi.org/10.1016/j.dental.2013.01.007.

2. Daiana Antonio Da Silva, Eduardo Coelho Marques Da Costa, Jorge Luiz De Franco. Reliability of directly-molded polymer surge arresters: Degradation by immersion test versus electrical performance. Electrical Power and Energy Systems 2013; 53: 488-498, http://dx.doi. org/10.1016/j.ijepes.2013.05.023.

3. He L, Yin C, Ping W, Yuan R, Huang HZ. Reliability and risk assessment of aircraft electric systems. Eksploatacja i Niezawodnosc Maintenance and Reliability 2014; 16 (4): 497-506.

4. Huang RQ, Xi LF. Residual life predictions for ball bearings based on self-organizing map and back propagation neural network methods. Mechanical Systems and Signal Processing 2007; 21: 193-207, http://dx.doi.org/10.1016/j.ymssp.2005.11.008.

5. Li DY, Liu CY. Study on the universality of the normal cloud model. Engineering Science 2004; 6(8): 28-34.

6. Li DY, Meng HJ, Shi XM. Membership clouds and membership cloud generators. Computers Research and Development 1995; 32(6): 16-21.

7. Li XJ, Liu LJ, Liu LZ. Evaluation of road network comprehensive reliability based on cloud theory and radar graph model. Application Research of Computer 2013; 30(10): 3007-3010.

8. Lv SJ, Zhang YS, Lou YH. Research of trusted technology based on cloud model. Application Research of Computer 2013; 30(8): 25232526.

9. Ma JM, Zhan XY. Performance reliability analysis of a Piston Pump affected by random degradation. Journal of Mechanical Engineering 2010; 46(14): 189-193, http://dx.doi.org/10.3901/JME.2010.14.189.

10. Min HH, Jeng SL, Shen PS. Assessing device reliability based on scheduled discrete degradation measurements. Probabilistic Engineering Mechanics 2009; 24: 151-158, http://dx.doi.org/10.1016/j.probengmech.2008.04.003.

11. M Nuhi, T Abu Seer, A Mal Tamimi. Reliability analysis for degradation effects of pitting corrosion in carbon steel pipes. Procedia Engineering 2011; 10: 1930-1935, http://dx.doi.org/10.1016/j.proeng.2011.04.320.

12. Ocak H, Loparo K A, Discenzo F M. Online tracking of bearing wear using wavelet packet decomposition and probabilistic modeling:A method for bearing prognostics. Journal of Sound and Vibration 2007; 302:951-961, http://dx.doi.org/10.1016/j.jsv.2007.01.001.

13. Olga Ink, Enrico Zio, Ulrich Weidmann. Predicting component reliability and level of degradation with complex-valued neural networks. Reliability Engineering and System Safety 2014; 121:198-206, http://dx.doi.org/10.1016/j.ress.2013.08.004.

14. Pan YN, Chen J, Li XL. Fuzzy c-means based equipment degradation assessment. Journal of Shanghai Jiaotong University 2009; 43(11): 1794-1797.

15. Pan ZQ, Narayanaswamy Balakrishnan. Reliability modeling of degradation of products with multiple performance characteristics based on gamma processes. Reliability Engineering and System Safety 2011; 96: 949-957, http://dx.doi.org/10.1016/j.ress.2011.03.014.

16. Qiang ZY, Feng J, Liu Q, Zhou JL. Reliability analysis based on performance degradation model of compound Poisson-Normal process. Systems Engineering and Electronics 2006; 28(11): 1775-1778.

17. Qin Y, Ju XG, Lu Q. A new reliability evaluation method based on cloud theory and stochastic process. Information and Control 2012; 41(4): 454-458.

18. Qin Y, Lu Q, Huang ST. A method of system performance evaluation based on the cloud theory and the information fusion theory. Computer Engineering and science 2012; 34(2): 181-185.

19. Ren SH, Xue F, Yv WW. Reliability residual-life prediction method for thermal aging based on performance degradation. Nuclear Power Engineering 2013; 34(5): 96-99.

20. Siljak H, Subasi A. Fourier spectrum related properties of vibration signals in accelerated motor aging applicable for age determination. Eksploatacja i Niezawodnosc - Maintenance and Reliability 2014; 16 (4): 616-621.

21. Sun ZQ, Zhao JY. Gamma process of degradation failure reliability analysis. Journal of Naval Aeronautical Engineering Institute 2010; 25(5): 581-584.

22. Tang JY, He P, Liang HQ. Comprehensive reliability assessment of long life products with correlated multiple failure modes. Journal of Mechanical Engineering 2013; 49(12): 176-182, http://dx.doi.org/10.3901/JME.2013.12.176.

23. Tan QN. The reliability modeling, analysis and comprehensive evaluation method of complex systems. PhD Thesis, Beijing: Beijing Jiaotong University, 2013.

24. Wang XD, Yi Z, Shen ZC. Proton radiation damage in ZnO-pigmented white paints and optical degradation mechanisms. Journal of Materials Engineering 2013; 3(5): 1-5.

25. Wang YJ, Jiang YC, Kang SQ. Diagnosis method of fault location and performance degradation degree of rolling bearing based on optimal ensemble EMD. Journal of Scientific Instrument 2013; 34(8): 1834-1840.

26. Wang Z, Pan R, Li XY, Jiang TM. A Bayesian reliability evaluation method with integrated accelerated degradation testing and field information. Reliability Engineering and System Safety 2013; 112:38-47, http://dx.doi.org/10.1016/j.ress.2012.09.015.

27. Wu L, Zhang ZM, Meng XC. Application of cloud theory in reliability assessment of combat aircraft. Computer Simulation 2005; 22(7): 235-236.

28. Yang H, Xu GN. Reliability Analysis on the data of performance degradation based on the blind number theory. Journal of Mechanical Strength 2013; 35(6): 777-782.

29. Yang H, Xu GN. Reliability analysis on the data of Performance degradation based on the fuzzy threshold. Journal of Construction Machinery 2013; 11(4): 19-23.

30. Yang K, Xue J. Continuous states reliability analysis. Proc. Annual Reliability and Maintainability Symposium, Philadelphia, PA, USA, 1316 January 1997: 175-176.

31. Yang WM, Sheng YX. Digital simulation of system reliability. Beijing: the Press of Beihang University, 1990.

32. Yang XM, Yuan JS, Wang JF. A new spatial forecasting method for distribution network based on cloud theory. Proceedings of the CSEE 2006; 26(6): 30-36. 
33. Yang Z, Chen YX, Li YF, Kang R. Smart electricity meter reliability prediction based on accelerated degradation testing and modeling. Electrical Power and Energy Systems 2014; 56: 209-219, http://dx.doi.org/10.1016/j.ijepes.2013.11.023.

34. Yan JH, Lee J. Degradation assessment and fault modes classification using logistic regression. Journal of Manufacturing Science and Engineering Transactions of the ASME 2005; 127: 912-914, http://dx.doi.org/10.1115/1.1962019.

35. Zhao JY, Liu F. Reliability assessment from accelerated performance degradation tests. Journal of Harbin Institute of Technology 2008; 40(10): 1669-1671.

36. Zhao JY, Liu F, Sun Q. Reliability analysis of Metallized-film pulse capacitor under competing failure modes. Systems EngineeringTheory\&Practice 2006; 26(1): 60-64.

37. Zhao JY. Study on reliability modeling and applications based on performance degradation. PhD Thesis, Changsha: China National University of Defense Technology, 2005.

38. Zhao JY, Sun Q, Zhou JL. Metallized film pulse capacitor based on the accelerated degradation data reliability analysis. Strong Laser and Particle Beams 2006; 18(9): 1495-1498.

\section{Heng YANG \\ Gening XU \\ Xiaoning FAN}

College of Mechanical Engineering

Taiyuan University of science and Technology

Waliu Road, No 66

Wanbolin District, Taiyuan, Shanxi Province, China

E-mail:yh-235@163.com , xugening@sina.com,fannyfxn@163.com 